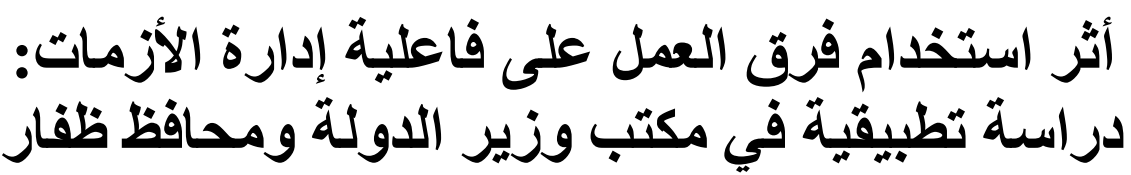

\title{
THE IMPACT OF TASK TEAMS ON THE EFFECTIVENESS OF CRISIS MANAGEMENT: AN APPLIED STUDY AT THE OFFICE OF THE MINISTER OF STATE AND THE GOVERNOR OF DHOFAR
}

\author{
Khawidam Mohammed Khawidam Ghawas ${ }^{1 \star}$, Dr. Tariq Mohammed Saleh ${ }^{2}$, Associate \\ Prof. Mohd Radhi bin Ibrahim ${ }^{3}$ \\ ${ }^{1}$ Ph.D Student at the Faculty of Leadership and Management, (USIM) Malaysia, \\ Khawidam.g@gmail.com \\ ${ }^{2}$ Senior Lecture at the Department of Commerce and Administrative Sciences, Dhofar University \\ ${ }^{3}$ Senior Lecture at the Faculty of Leadership and Management, (USIM) Malaysia \\ ${ }^{*}$ Corresponding author
}

\begin{abstract}
The aim of this quantitative research is to find out the impact of the use of task teams on the effectiveness of crisis management in the Office of the Minister of State and the Governor of Dhofar. The problem of research arises when forming up task team at the Minister of State Office for Crisis Management. These teams face challenges to varying degrees during the implementation of the tasks assigned to them. The researcher adopted the descriptive analytical method. The research community consists of (120) employees at the Minister Office. A random sample of (69) employees was selected. The findings revealed that there is a weak positive correlation between the constraints of the use of teams and crisis management. And the existence of a significant statistical effect at the level of significance (0.05) between the constraints of the use of teams and crisis management. (0.05) for the effectiveness of the crisis management teams in the office of the Minister of State and the Governor of Dhofar. The researcher recommended that the system of incentives and rewards be amended to motivate employees to join the teams.
\end{abstract}

Keywords: task teams, crisis management, effectiveness.

هدف هذا البحث الكمي إلى معرفة أثز استخدام فرق العمل على فاعلية إدارة الأزمات، في مكتب وزير

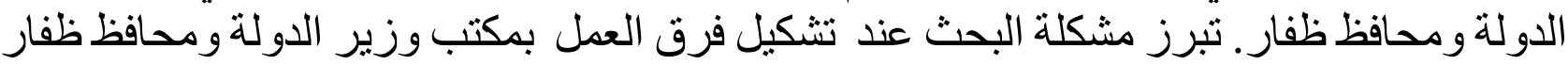
لإدارة الأزمات، و هذه الفرق تو اجه تحديات بدرجات متفاونة خلال تتفيذها المهام المناطة بها.

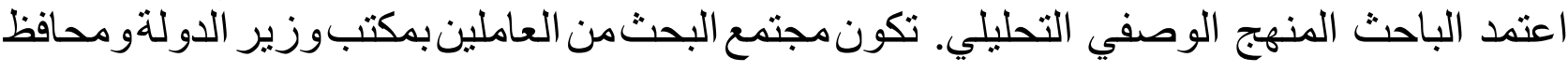


ظفار البالغ عددهم (120) موظفا وموظفة. وتم اختيار عينة عشو ائية قدرها (69) موظفاً. بينت

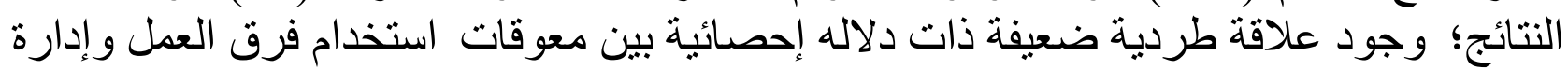

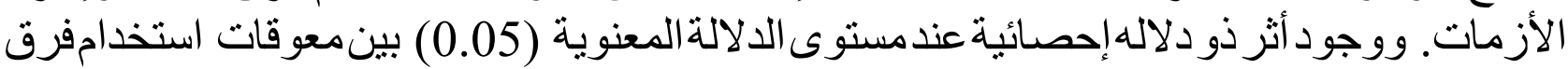

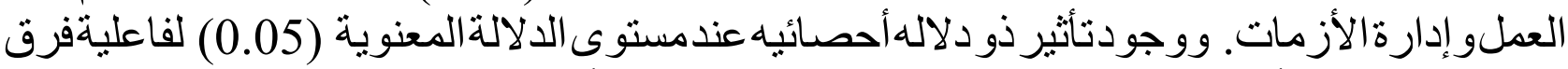

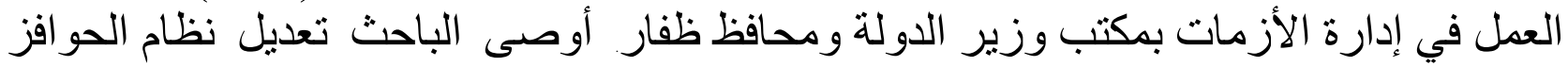

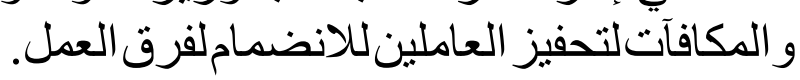
الكلمات المفتاحية: فرق العمل، إدارةالأزمات، الفانفين الفاعلية

المقدمة:

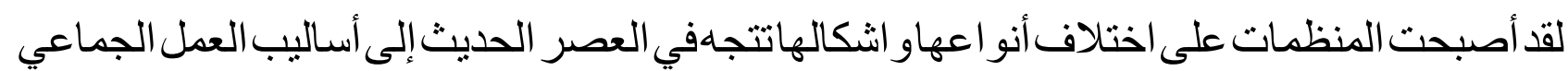

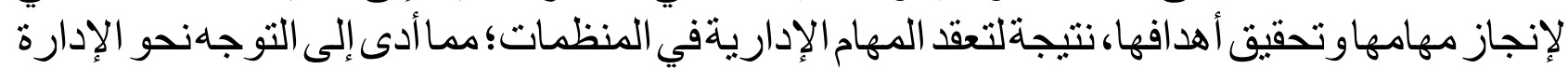

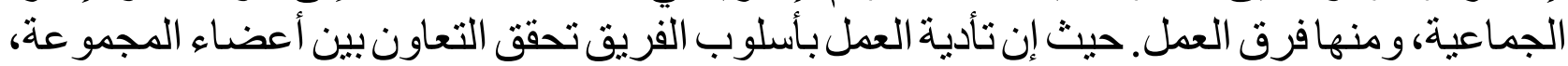

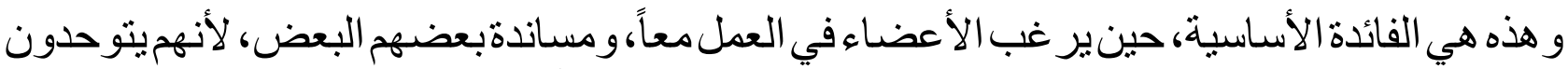

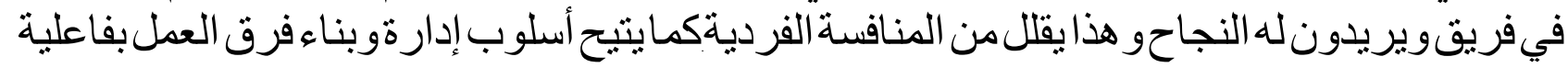

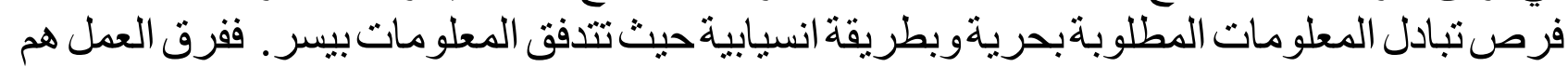

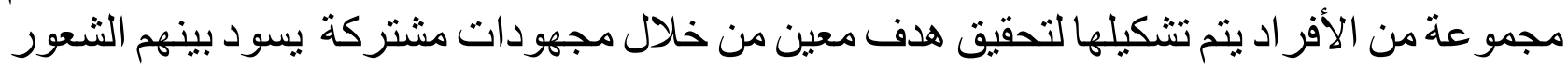

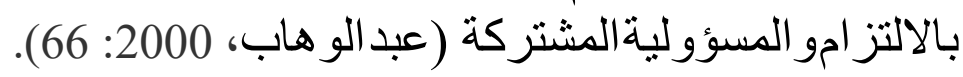

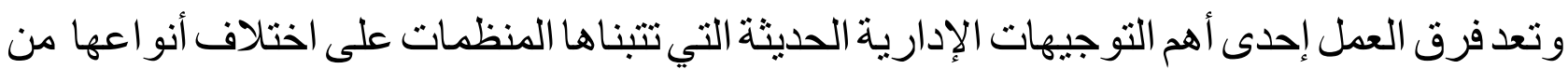

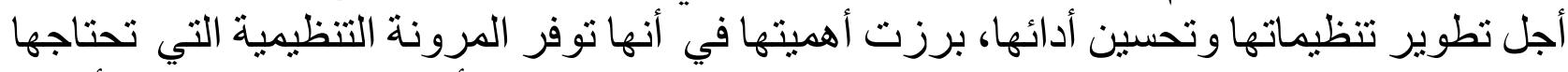

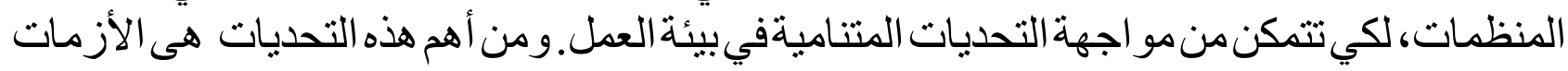

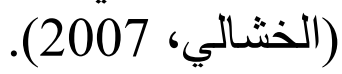

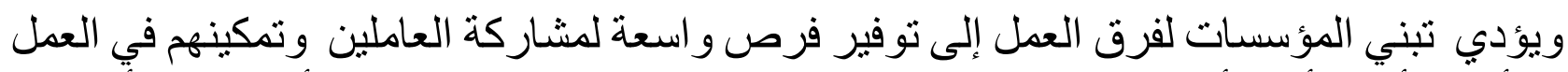

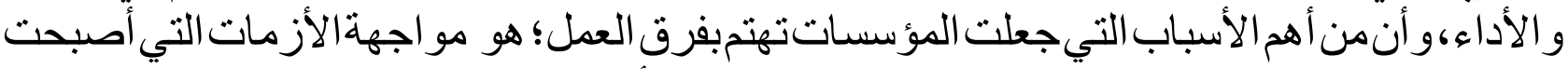

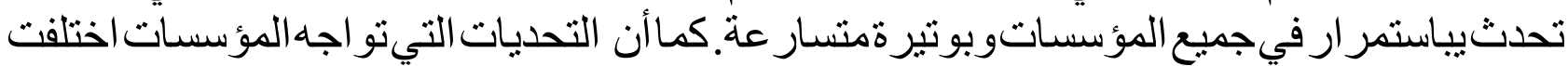

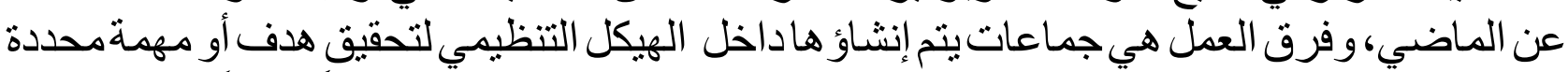

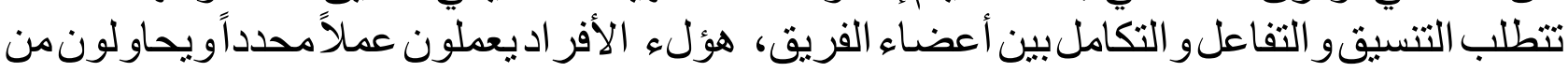

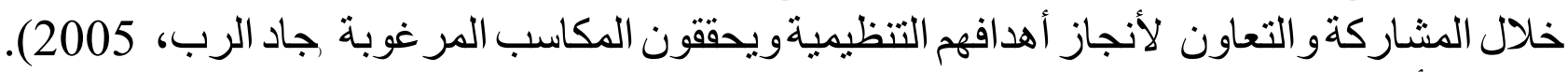

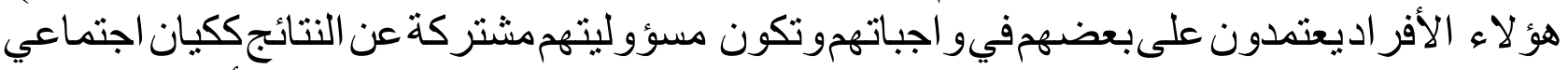

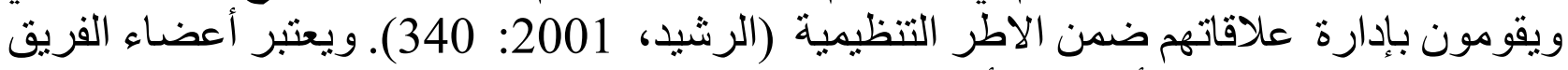

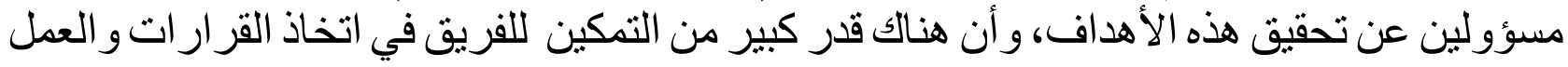

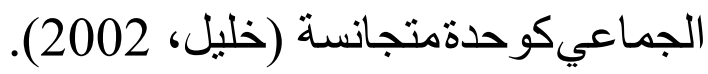

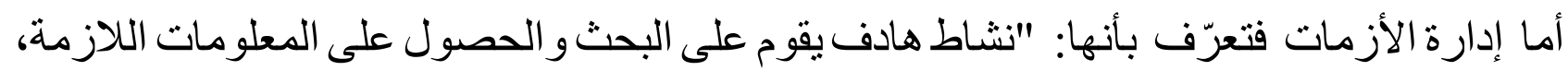

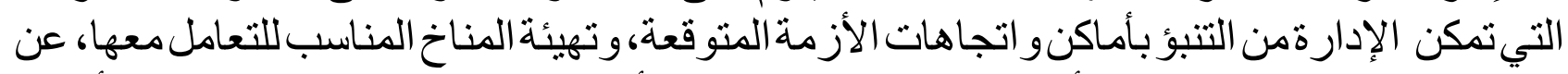

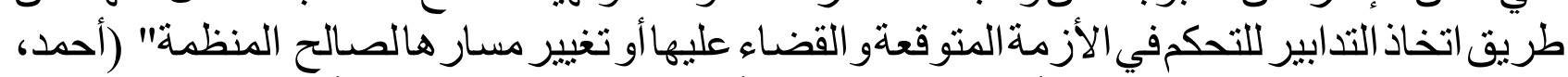

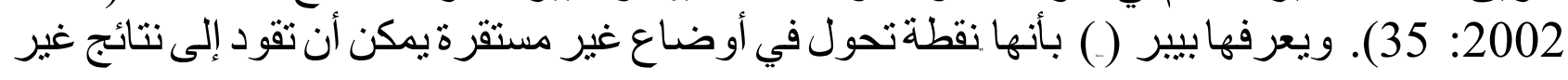


مر غوب فيها إذا كانت الأطر اف المعنية غير مستعدة أو غير قادرة على احتو ائها أو در ه مخاطر ها جبر ، . $67: 2000$ مشكلة الاراسة: مئر

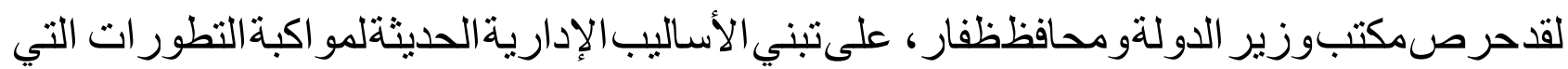

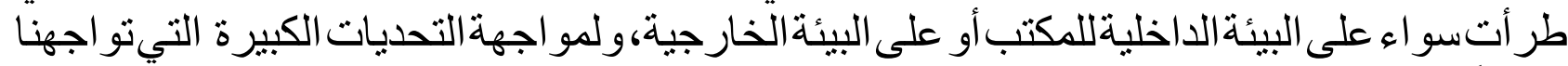

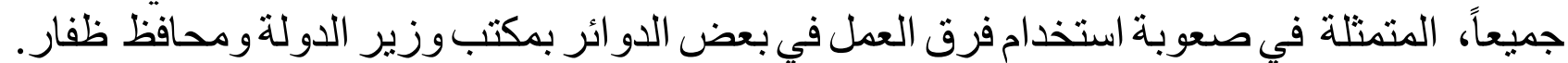

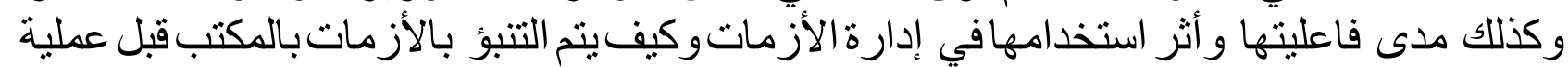

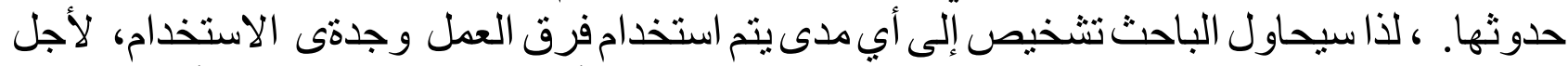

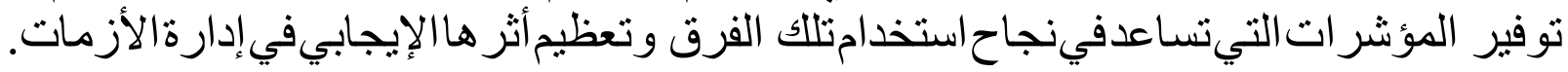
أهداف الاراسة:

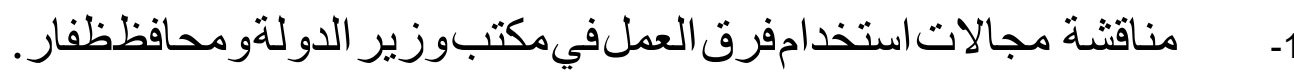

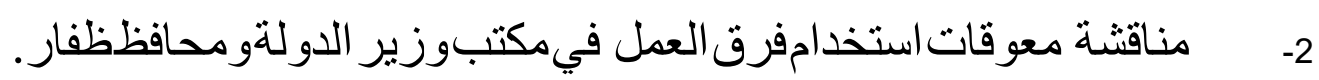

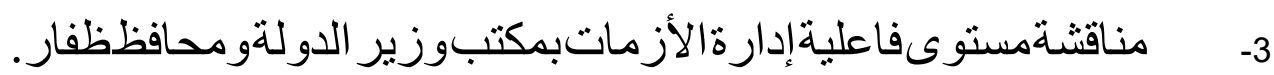

الإطار النظري: يمكن تقسيمفرق العمل إلى الإطى

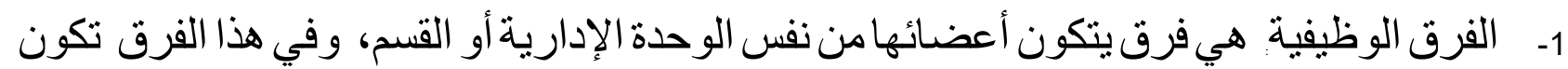

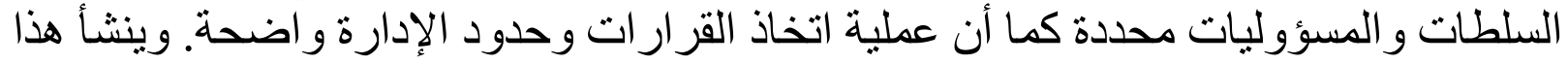

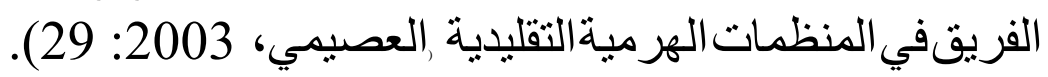
2- فرق متعددة الوظائف: تتكون من مجمو عة من العاملين الذين يمتلكون المهار ات و الخبرة العالية،

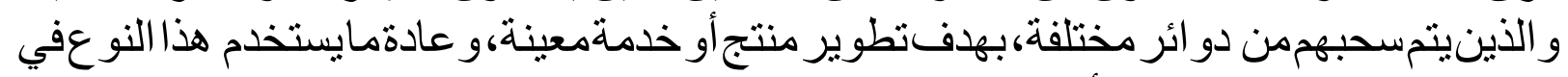
ظل التغيير ات السريعة في الأسو اق، وذللك لسر عة الاستجابة لاحتياجات المرئة المر اجعين و المستهلكين

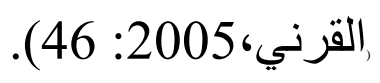

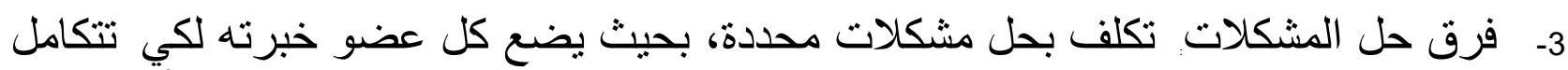

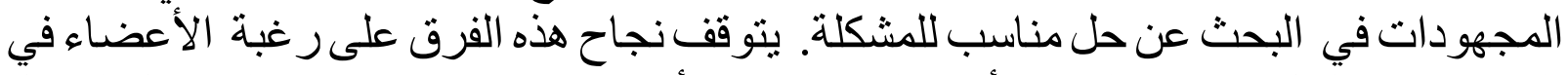

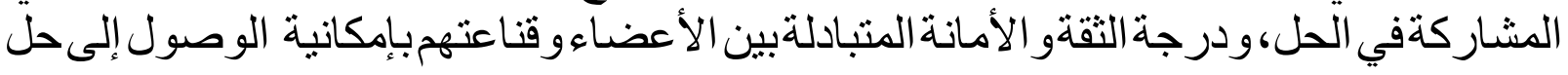

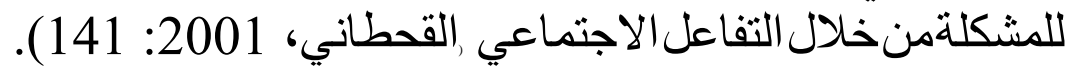

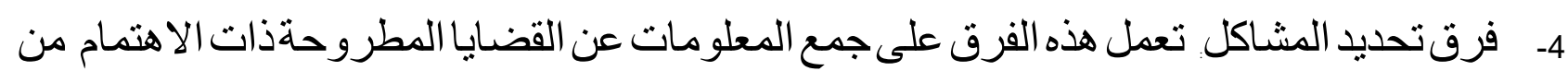

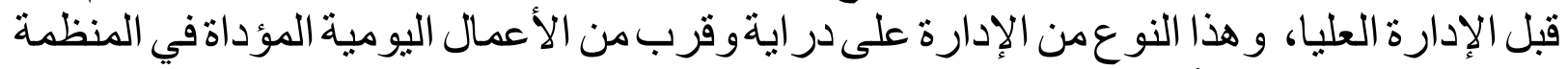

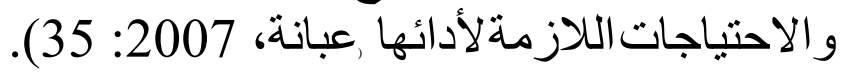

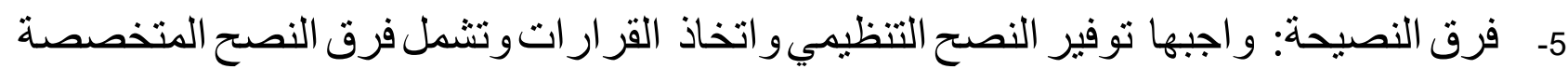

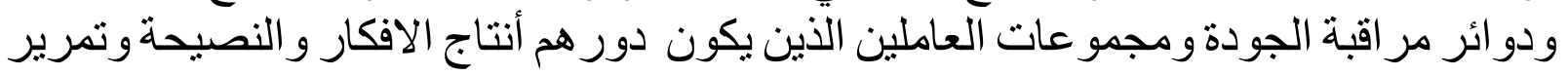




$$
\text { الاقتر احات حسن، 2002: 209). }
$$

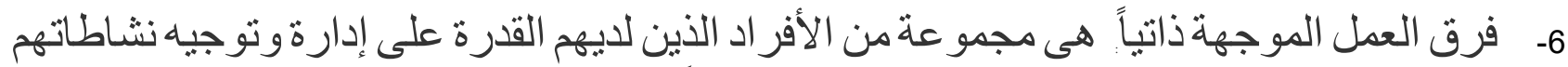

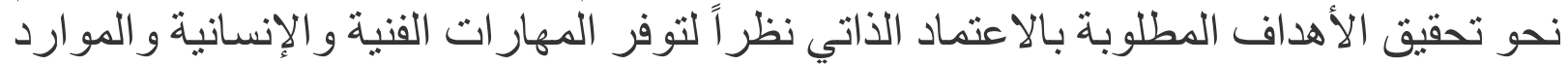

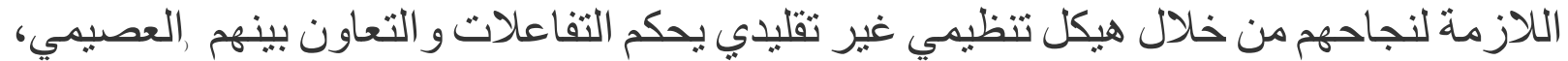

7- فرق العمل الافتر اضية:نجمت هذه الفرقنتيجةتأثير استخدامتكنولو جيا المعلومات والاتصالات

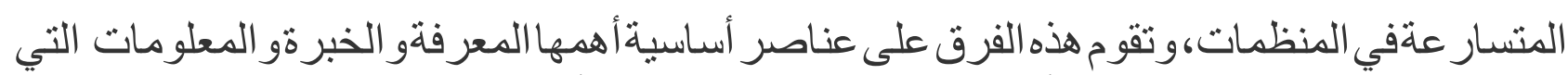

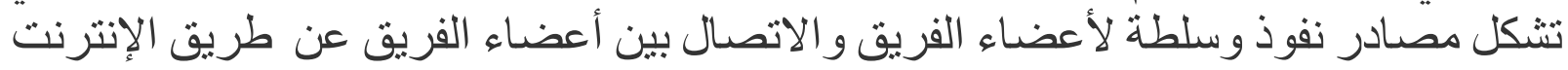
و المؤتمر ات و البريد الإلكتروني وجماعات النقاش و غير ها من وسائل الاتصال الحديثة (الرشيد، الإتيد

يشير مفهو مإدارة الأزمة إلى كيفية التغلب على الأزمة باستخدام الأسلوب الإداري العلمي من أجل تلافي

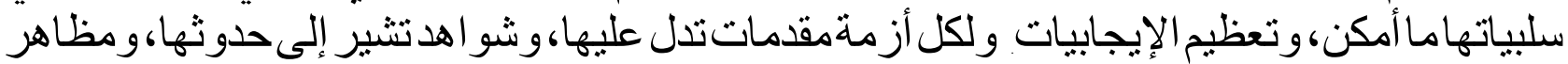

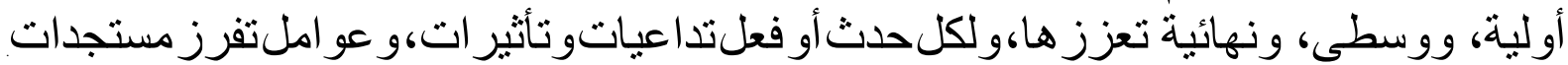
الثكل (1) أسباب نشوء الأزمات

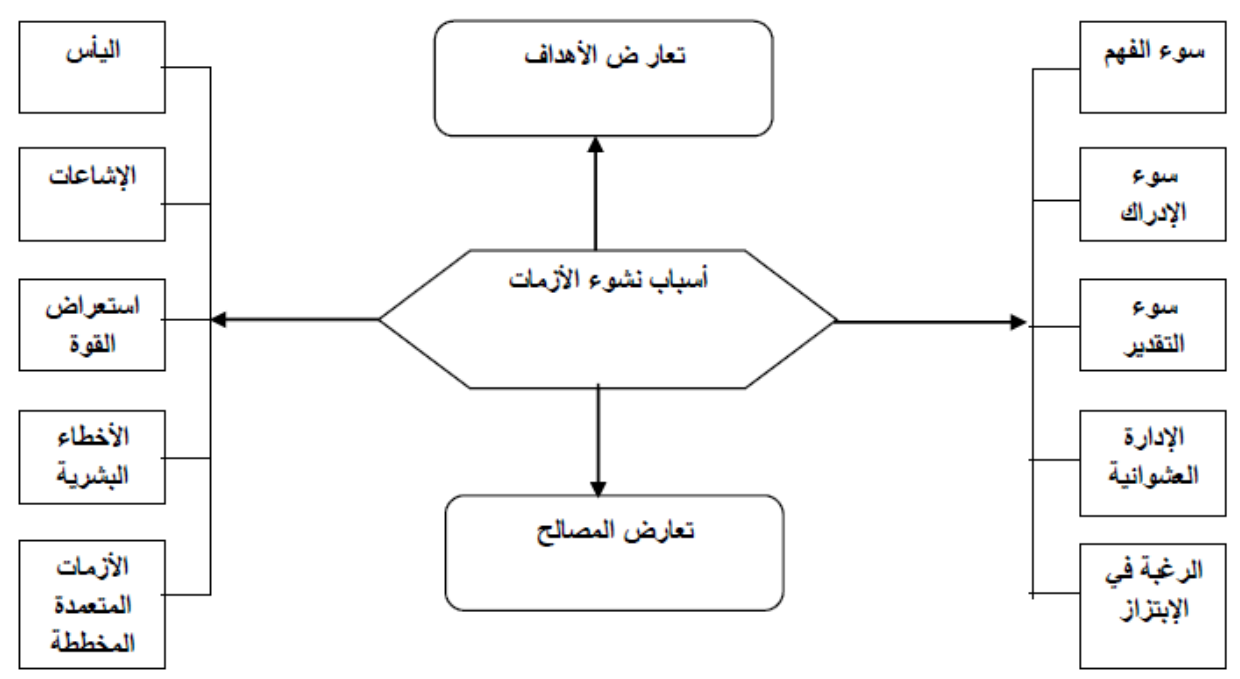

المصدر : الخضيري (2002)

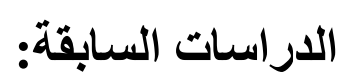

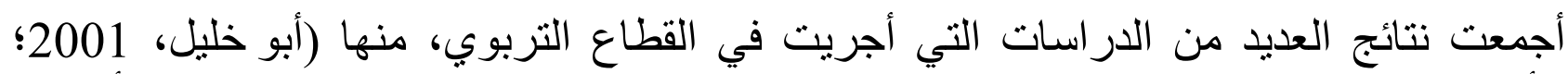

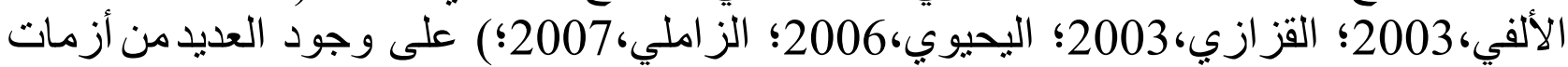

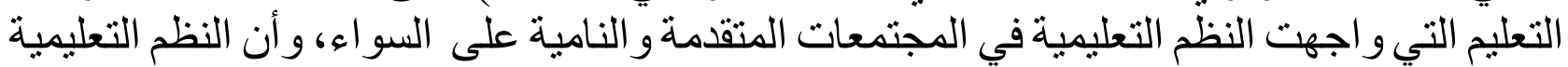

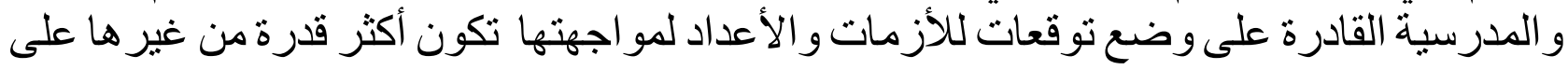


تجاوز هابسر عةوفاعلية

كما أكدت نتائج دراسات عربية أخرى (القحطاني، 2007 2003؛ الفهيد؛ 2006؛

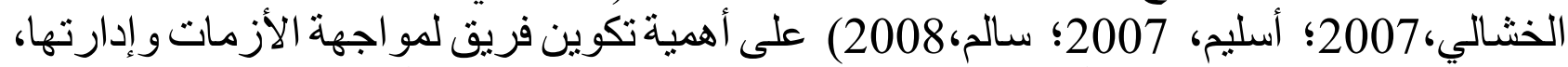

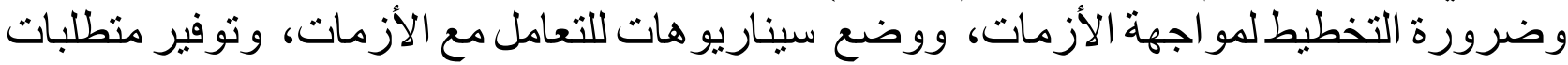

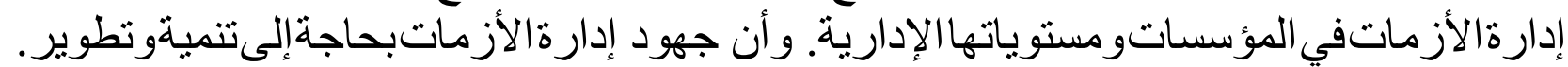

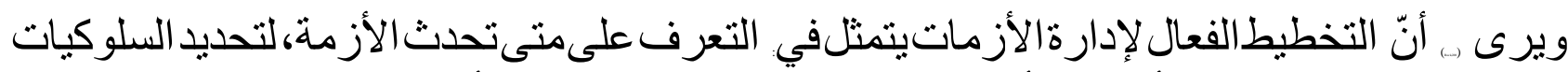

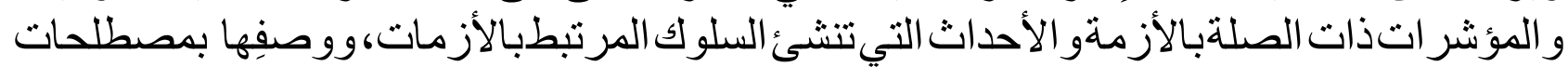

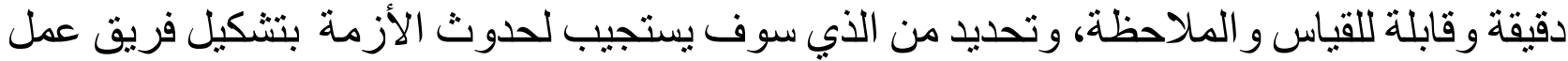

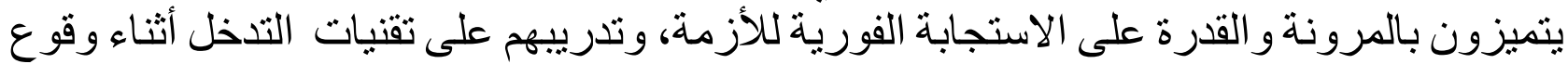

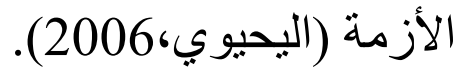
جاء في در اسة أبو خليل، (2001) حول موقف مديري مداري مدارس التعليم الأساسي من بعض الأزمات

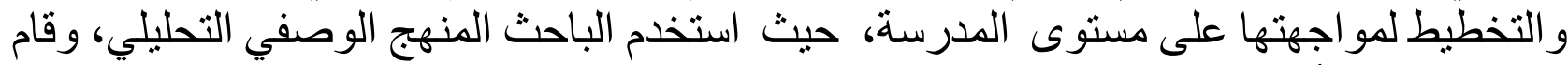

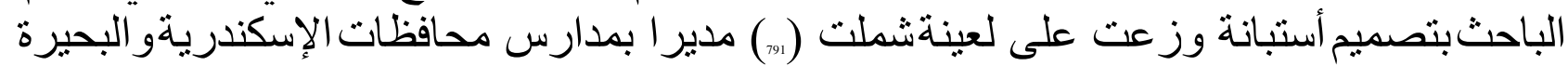

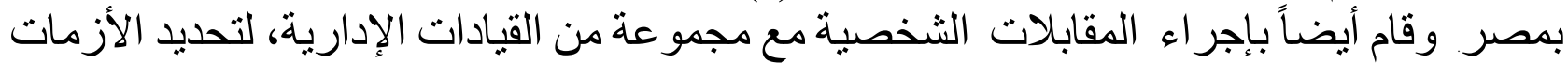

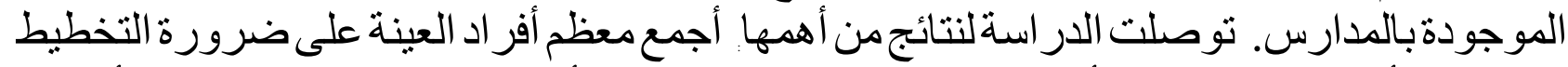

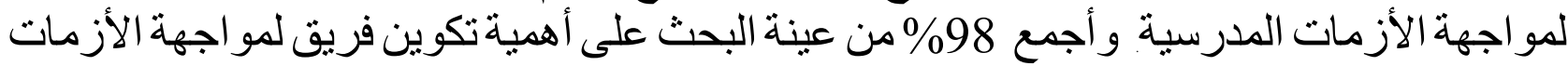

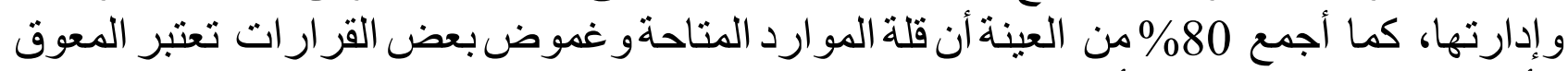

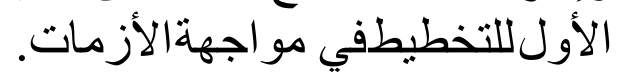

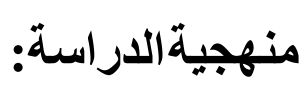

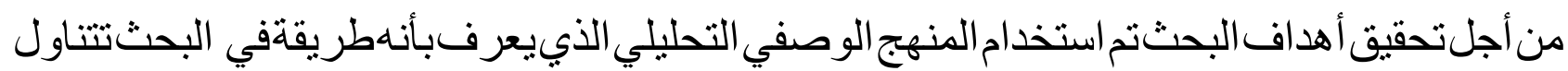

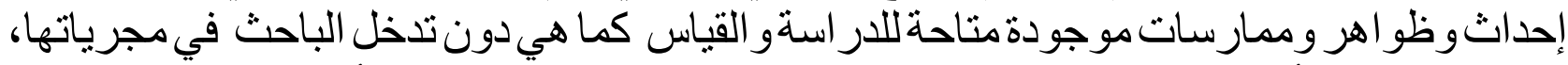

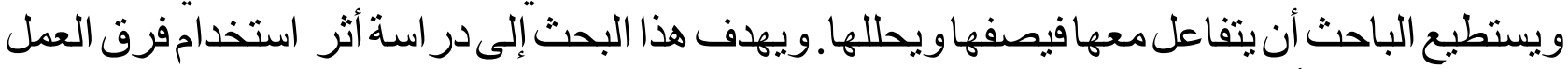
في فاعلية إدارة الأزمات

مجتمع البحث وعينته: تكون مجتمع البحث من العاملين بمكتب وزير الدولة لةو محافظظفار ، البالغ عددهم

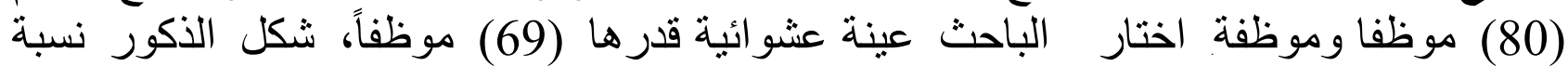

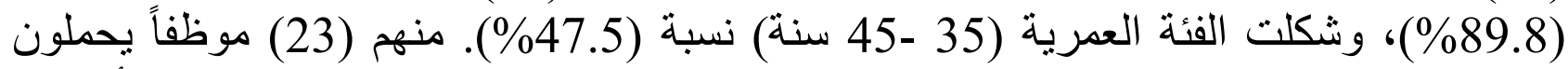

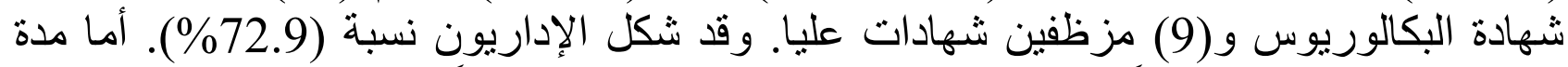

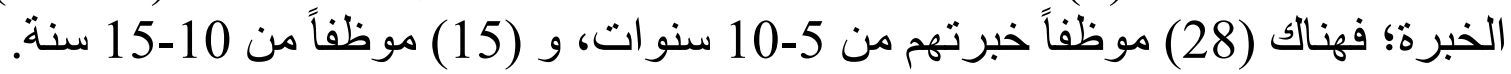
أداة الدراسة: صممت الاستبانةوفق مقياس ليكرت الخماسي، وتتكون من ثناث أقسام هي القسم الأول: البيانات الثخصية. القسم الثاني: آر اء أفر اد عينةالبحثن البحو فرق العملو تظممجمو عتين:

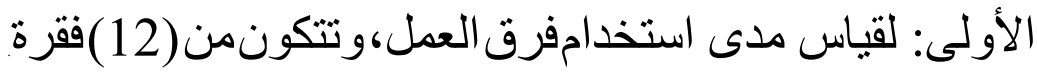
الثانية: لقياسمعوقات استخدامفرق العمل،ونتكونمن (15)فقرة 
القسم الثالث يتتاول آر اء أفر اد عينةالبحثنحو إدارة الأزماتو تتكونمن(15)فقرة

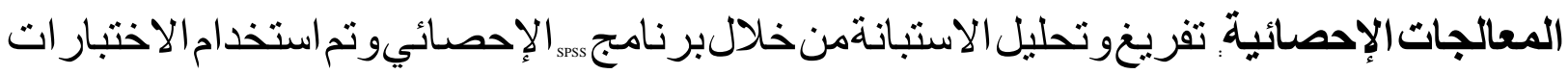
الإحصائيةالتالية

1- التكر ار اتو النسب المئويةلوصف خهصائص أفر اد العينة 2- اختبار ألفاكرونباخ لمعر فةتنبات فقر ات الاستبانة

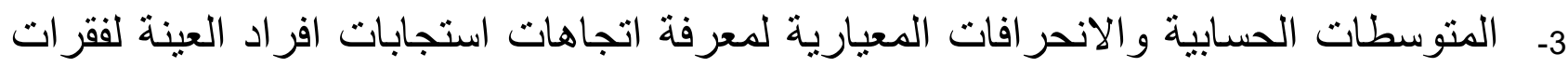
الاستبانة.

4- معامل ارتباطبيرسون لقياس العلاقةبينمتنغير ات البحث

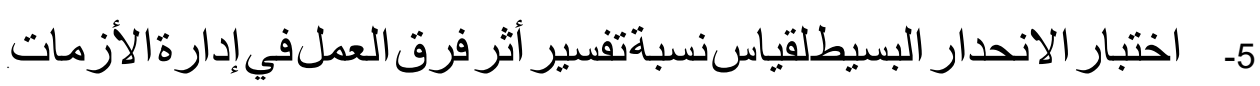

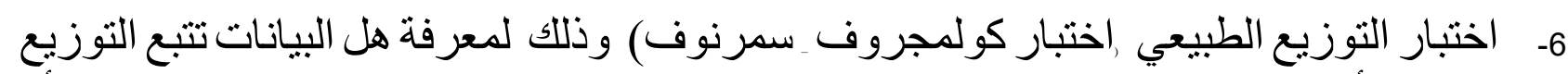

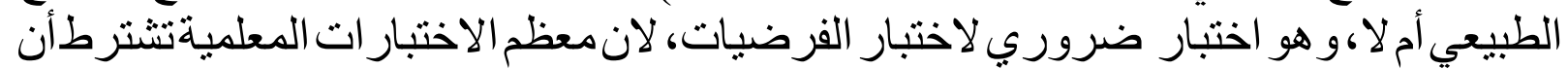

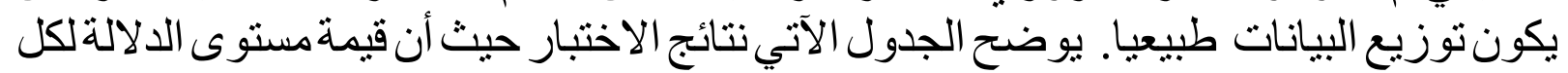

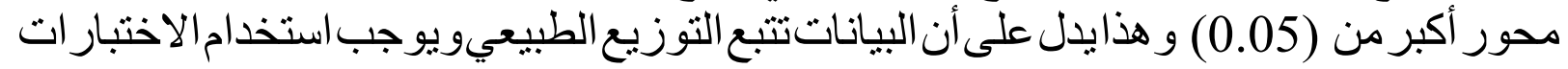
المعلميه

تم الاعتماد على المعيار الموضح في الجدول التالي في تقدير مستوى المو افقةلدى المفحوصين في ضوء

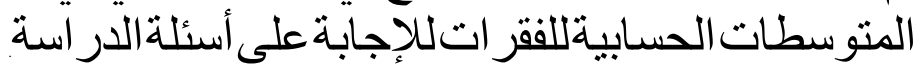
الجدولرقم(1) المستو يات المتحققة المقابلةلمدى المتوسطات الحسابية

\begin{tabular}{|c|c|}
\hline الأهمية النسبية & المتوسط الحسابي \\
\hline منخفضة جداً & $1.7-1$ \\
\hline منخفضة & $2.5-1.8$ \\
\hline منوسطة & $3.3-2.6$ \\
\hline مرتفعة & $4.1-3.4$ \\
\hline مرتفعة جداً & 4.2 - فأكثر \\
\hline
\end{tabular}

$$
\text { المصدر (عبد الفتاح،2007) }
$$

تم إجر اء اختبار (كولمجروف سمرنوف) لمعرفة هل البيانات تتبع التوزيع الطبيعي أم لا،وهو هو اختبار

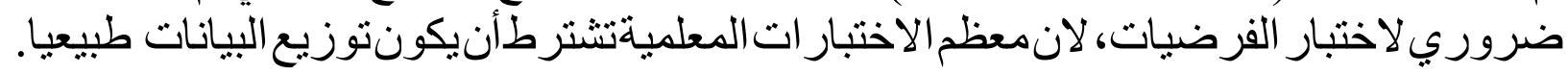
جدولرقم(2) اختبار التوزيع الطبيعي(كولومجروف الانسمرنوف

\begin{tabular}{|c|c|c|c|c|}
\hline مستوى الدلالة & قيمة & عدد الفقرات & عنوان المحور & المحور \\
\hline
\end{tabular}


IJASOS- International E-Journal of Advances in Social Sciences, Vol. V, Issue 13, April 2019

\begin{tabular}{|c|c|c|c|c|}
\hline .712 & .700 & 12 & استخدامفرق العمل & الأول \\
\hline .802 & .644 & 15 & معوقات استخدامفرق العمل & الثاني \\
\hline 902 & .570 & 15 & إدارة الأزمات & الثالث \\
\hline
\end{tabular}

يوضح الجدول آنفاًنتائج الاختبار حيث أنقيمةمستوى الدلالةلكلمحور أكبر من (0.05)؛ و هذايدل على أن البيانات تتبع التوزيع الطبيعي. نتائج الاراسة:

الإجابة عن السؤالالأول مامجالات استخدامفرق العملفيمكتبوزير الدولة و وحافظظفار؟ للإجابة على هذا السؤ ال استعان الباحث بكل من المتوسطات الحسابيةو الانحر افات المعيارية، و لأهمية النسبيةللفقرة، كما هو موضحبالجداولالالآلتية

الجدولرقم(3) المتوسطات الحسابيةو الإنحر افات المعياريةو الأهمية النسبيةفي استخدامفرق العمل

\begin{tabular}{|c|c|c|c|c|c|}
\hline 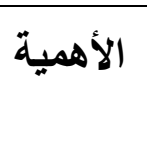 & ت الفقرة & 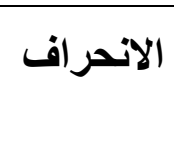 & المتوسط & 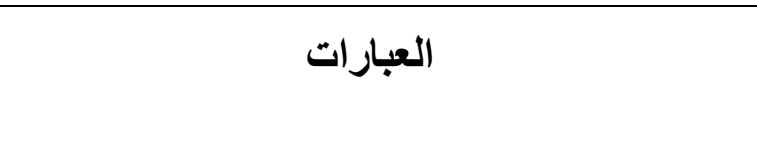 & $ت$ \\
\hline مرتفعة & 1 & .798 & 4.14 & تستخدمفرق العملبهدف تطويروتحسين إجر اءات & 3 \\
\hline مر تفعة & 2 & .938 & 3.98 & يتم اللجوء إلى فرق العمل لتخطيطو معالجة الأزمات & 10 \\
\hline 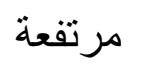 & 3 & .890 & 3.97 & تستخدمفرق العمل لحل المشاكل التيتو اجها الإدارة & 1 \\
\hline 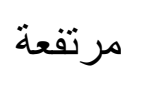 & 4 & .969 & 3.69 & يتم اللجو ء إلىفرق العمل لتحسين مستوى الاداء & 4 \\
\hline 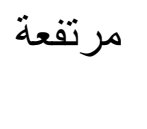 & 5 & 1.000 & 3.61 & جديدة الاستعانةبفرق العمل عند إنشاء إدار ات أو مر اكز & 5 \\
\hline 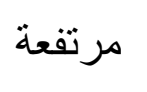 & 6 & 1.100 & 3.59 & توظف فرق العمل فيتنفيذحملات التو عية & 9 \\
\hline 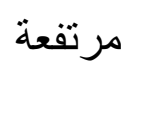 & 7 & .932 & 3.58 & تلجطا الإدارة إلىى استخدامفرق العملفية مجالوضع & 2 \\
\hline 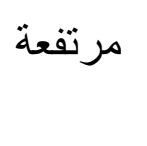 & 8 & 1.104 & 3.45 & وتنفيذهامفرق العملفي إعداد البر امج التدريبية & 6 \\
\hline 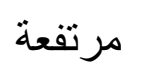 & 9 & .953 & 3.46 & تستخدمفرق العمل عند التنسيقمع الإدار ات الأخرى & 11 \\
\hline
\end{tabular}


IJASOS- International E-Journal of Advances in Social Sciences, Vol. V, Issue 13, April 2019

\begin{tabular}{|c|c|c|c|c|c|}
\hline مرتفعة & 10 & 1.103 & 3.44 & و توظف اللو ائحرق العمل عند الحاجةلتعديل الأنظمة & 12 \\
\hline متوسطة & 11 & 1.010 & 3.34 & تستخدمفرق العمل عندر غبة الإدارةفيشر اء أجهزة & 7 \\
\hline متوسطة & 12 & 1.139 & 3.25 & و التعبين اللجو ؛ إلى فرق العمل عند إجر اء المقابلات & 8 \\
\hline مرتفع & & .995 & 3.63 & المعدل العام & \\
\hline
\end{tabular}

يلاحظمن الجدول آنفاً أن استخدامفرق العملبمكتب وزير الدولة لقو محافظظفار كانتمر تفعة الأهميةمن

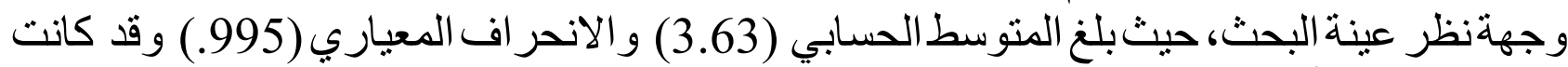

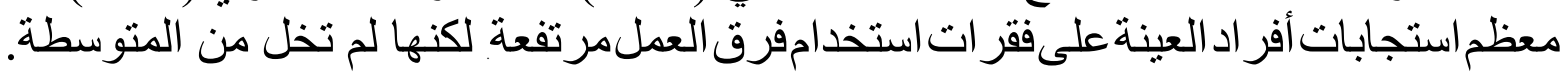

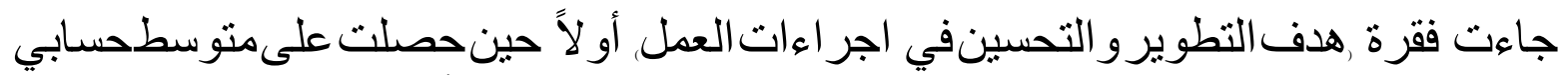

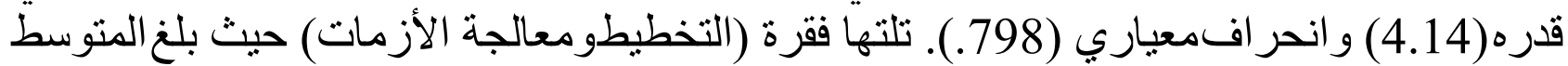

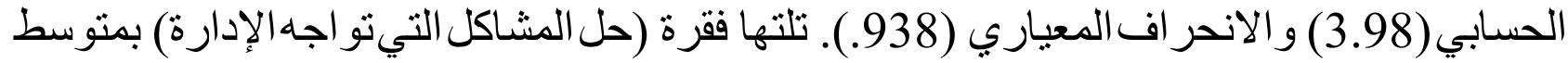

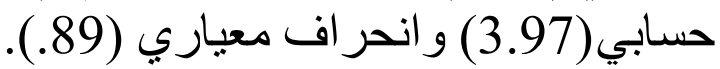

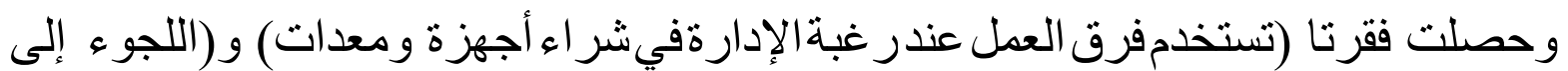

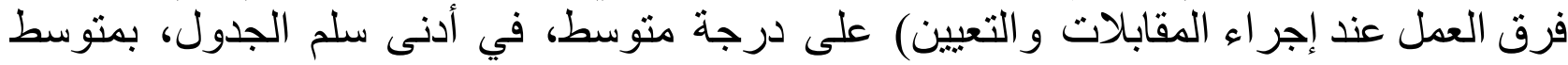

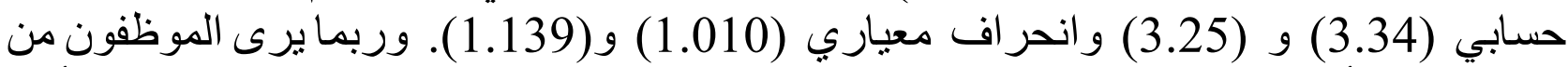

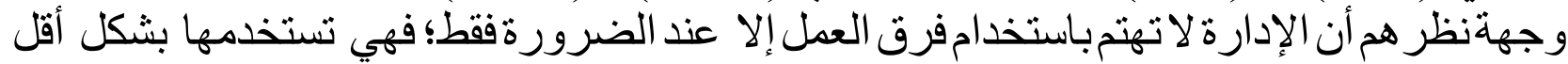

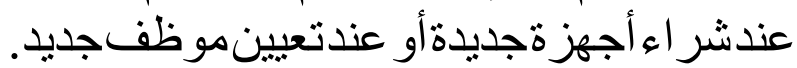

الإجابة عن السؤال الثاني: ما معوقات استخدامفرق العمل فيمكتب وزير الدولة الدون ومحافظظفار؟ الجدول(4) المتوسطات الحسابيةو الإنحر افات المعياريةو الأهية:النسبيةل لمعوقات استخدامفرق العمل

\begin{tabular}{|c|c|c|c|c|c|}
\hline الأهمية & ترثيب & الانحراف & المتوسط & العبارات & ت \\
\hline مرتفعة & 1 & .993 & 3.75 & للانضعف نظام إلى فرق العزو المكافآت لتحفيز العاملين & 22 \\
\hline مرتفعة & 2 & 1.021 & 3.69 & ثلى المصة المنظمةتشجُع على تفهم تقديم مصلحة الجماعة & 27 \\
\hline مرتفعة & 3 & .958 & 3.66 & 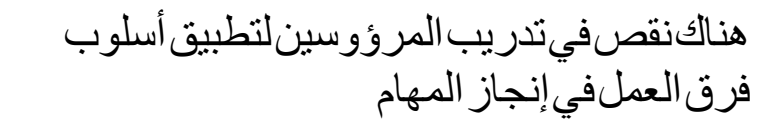 & 16 \\
\hline مرتفعة & 4 & .869 & 3.63 & هنالكو عيبأهمية العمل الجماعي & 26 \\
\hline
\end{tabular}


IJASOS- International E-Journal of Advances in Social Sciences, Vol. V, Issue 13, April 2019

\begin{tabular}{|c|c|c|c|c|c|}
\hline 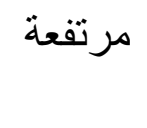 & 5 & 1.088 & 3.53 & الإدارة إتات القانونيةتحدمن استخدامفرق العملفي & 13 \\
\hline مرتفعة & 6 & 1.071 & 3.44 & العمل العاء الإداريةقليلة القدرة علىتطبيق أسلوبفرق & 18 \\
\hline متوسطة & 7 & 1.032 & 3.37 & الفريق هناكنيفي التأهيل العلمي اللازم للعمل بروح & 15 \\
\hline متوسطة & 8 & .990 & 3.32 & يوجد عدم انسجامفيفلسفة الإدارةمع أسلوبفرق & 21 \\
\hline منوسطة & 9 & 1.041 & 3.32 & 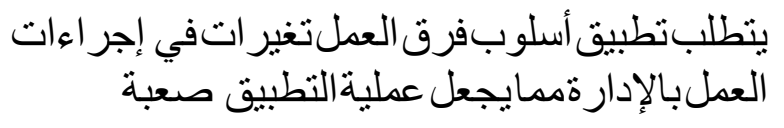 & 20 \\
\hline متوسطة & 10 & 1.099 & 3.29 & تشكيلفرقر العمل بين العاملينفي الإدارةيحولدون & 19 \\
\hline متوسطة & 11 & 1.194 & 3.24 & العاملون اعتادو اعلى القيامبمهامهمبشكلفردي & 23 \\
\hline متوسطة & 12 & .962 & 3.15 & الإدارة العلياتعارض تطبيق أسلوبفرق العمل & 14 \\
\hline منوسطة & 13 & 1.065 & 3.07 & مهامهم غير كافيلتطبيق أسلوبفرق العمل لإنجاز & 17 \\
\hline متوسطة & 14 & 1.127 & 3.07 & يو جدتدنيفي مستوي الثقةبين الإدارةو العاملين & 25 \\
\hline 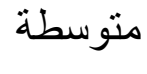 & 15 & 1.152 & 3.02 & طبيعة العملتشجع على العمل الفردي & 24 \\
\hline متوسطة & & 1.044 & 3.37 & المعدل العام & \\
\hline
\end{tabular}

اثنارت النتائج في الجدول أعلاه إلى أن معوقات استخدام فرق العمل بمكتب وزير الدولة ومحافظظف التفار

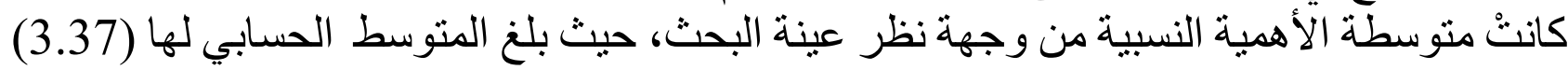

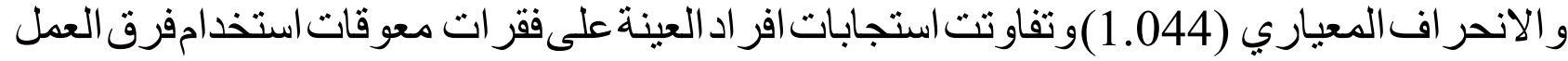
بين المتوسطة المرافي المفعة، وكانت في معظمها متوسطة.

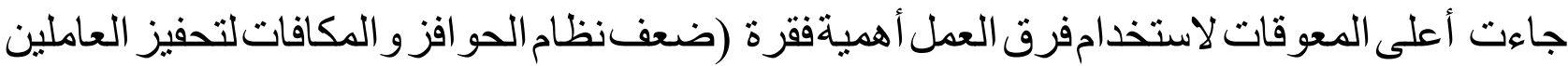
للانضمام عليفرق العمل، التي حصلت على منو سطحسابيقدره (3.75) و انحر اف لمعياري (993.

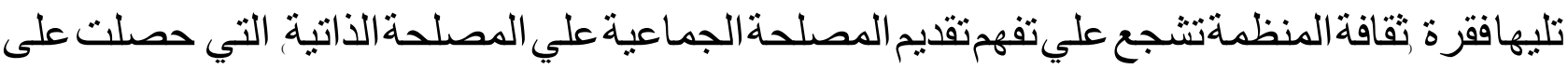

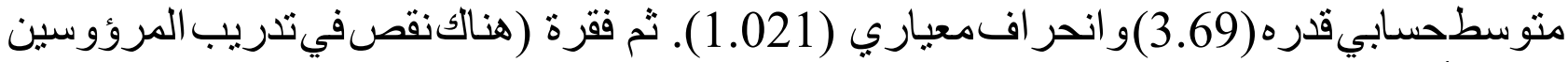

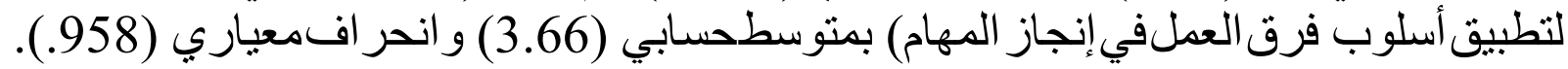




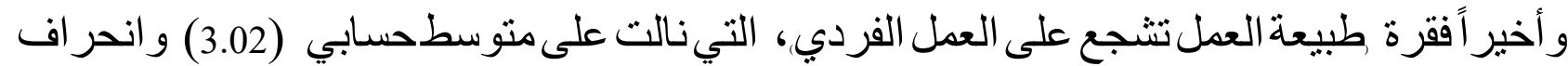

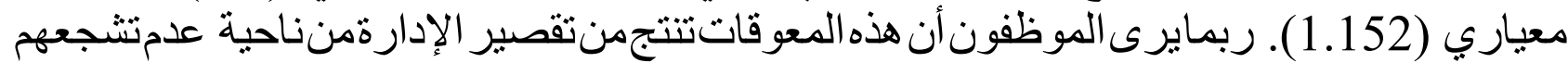

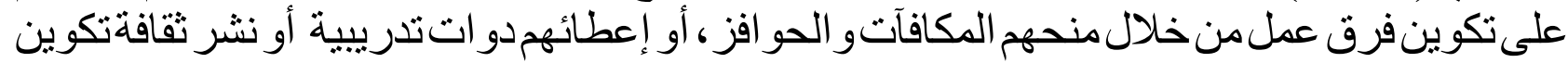

نص السؤ الالثالث: مامستوى فاعلية إدارة الأزماتفي مكتب وزير الدولة ومحافظظفار؟ للإجابة على هذا السؤ ال استعان الباحث بكل من المتو سطات الحسابيةو الانحر افات المعيارية و الأهمية

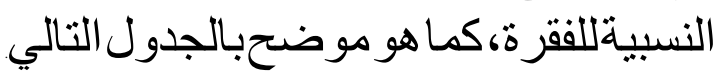
الجدول(5) المتوسطات الحسابيةو الانحر افات المعياريو الأهميةلاستجابات بعد إدارةالأزمات

\begin{tabular}{|c|c|c|c|c|c|}
\hline الأهمية & ترتيب & الانحراف & المتوسط & العبارات & $ت$ \\
\hline مرتفعة & 1 & .691 & 4.07 & 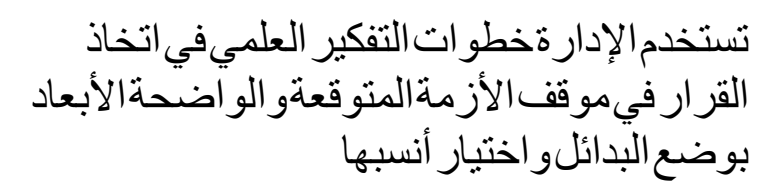 & 28 \\
\hline مرتفعة & 2 & .729 & 4.05 & 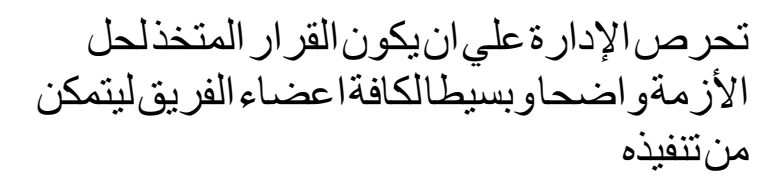 & 33 \\
\hline مرتفعة & 3 & .754 & 3.98 & 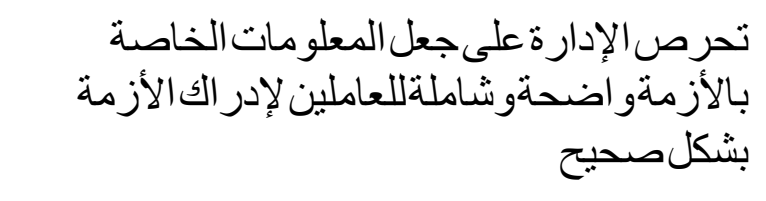 & 38 \\
\hline مرتفعة & 4 & .853 & 3.88 & 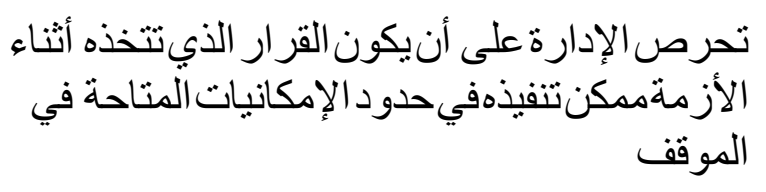 & 41 \\
\hline مرتفعة & 5 & .966 & 3.88 & 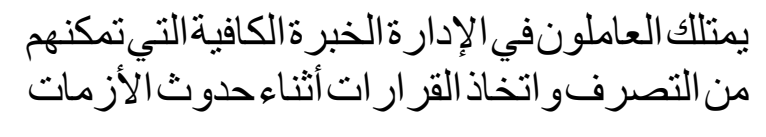 & 30 \\
\hline مرتفعة & 6 & .973 & 3.86 & 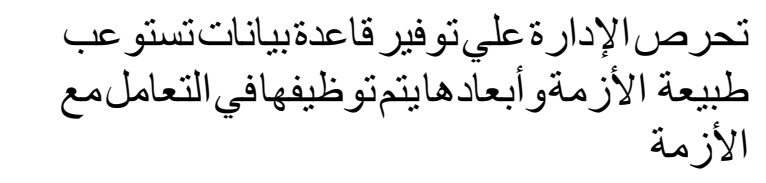 & 42 \\
\hline مرتفعة & 7 & .733 & 3.75 & 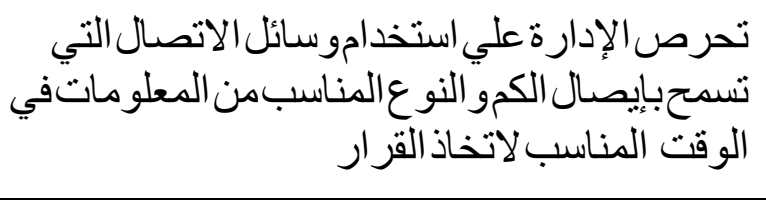 & 37 \\
\hline مرتفعة & 8 & .983 & 3.71 & تحرص الإدارة على أنيلقي القر ار المتخذفيموقف & 32 \\
\hline
\end{tabular}




\begin{tabular}{|c|c|c|c|c|c|}
\hline & & & & الأزمةتجاوبو قبول كافة العاملين & \\
\hline مرتفعة & 9 & 1.077 & 3.66 & 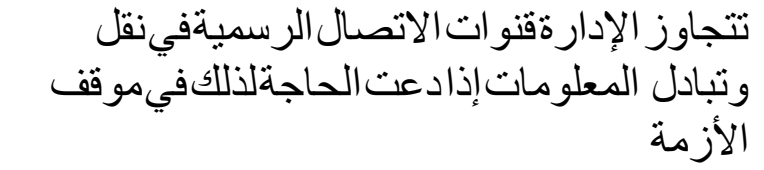 & 34 \\
\hline مرتفعة & 10 & .943 & 3.64 & تصناسب الإدارة القر ار ات المتعلقةبالأزمةفيوقت & 29 \\
\hline مرتفعة & 11 & .869 & 3.63 & 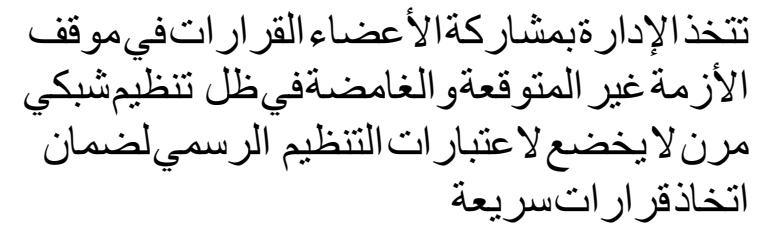 & 31 \\
\hline مرتفعة & 12 & .889 & 3.63 & تحرص الإدارة عليتبويب المعلومات الخاصة & 39 \\
\hline مرتفعة & 13 & 1.023 & 3.51 & 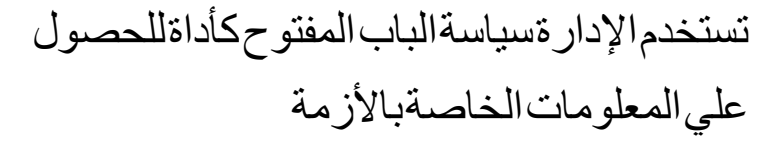 & 36 \\
\hline مرتفعة & 14 & 1.040 & 3.51 & الوات العافقة الإدارةتنظام اتصاليسمحبتبادل المعلومات & 35 \\
\hline مرتفعة & 15 & 1.036 & 3.41 & 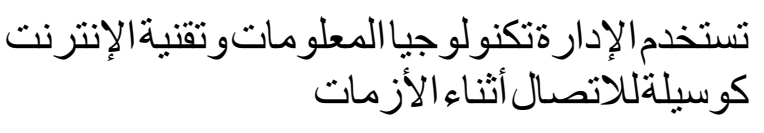 & 40 \\
\hline مرتفعة & & .904 & 3.74 & المعدل العام & \\
\hline
\end{tabular}

بينت النتائج في الجدول أعلاه إلى أن فاعلية إدارة الأزمات بمكتب وزير الدولة ومحافظظفار كانت

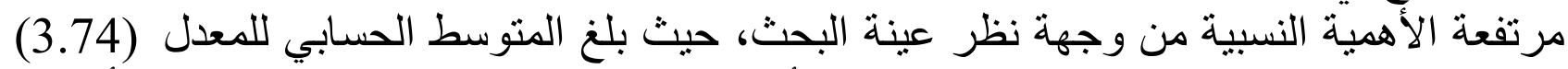
و الانحر اف المعياري (904.) وكانتْ استجابات أفر اد العينة على جميع فقر ات فاعلية الفية إدارة الأزمات مرتفعة

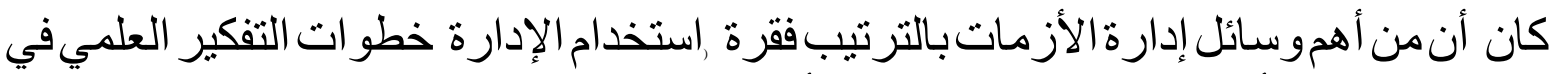

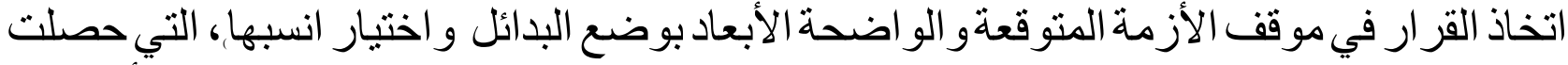
على منوسط حسابي قدره (4.07) و انحر اف معياري (691.

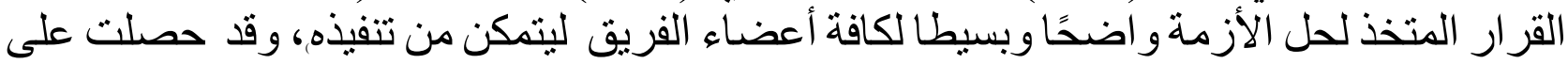

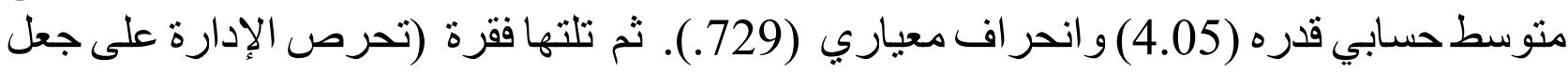


المعلومات الخاصة بالأزمةو اضحةوشاملة للعاملين لإدر الك الأزمةبشكل صحيح) حيث حصلت على (3) حلى منوسطحسابيقدره(3.98)و انحر افمعياري (754.

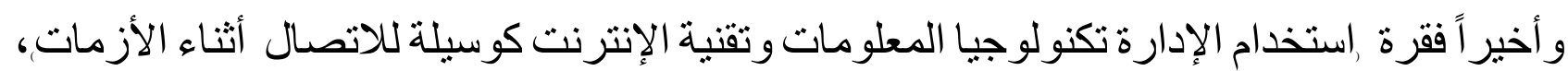

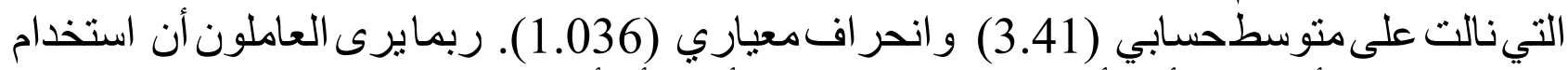

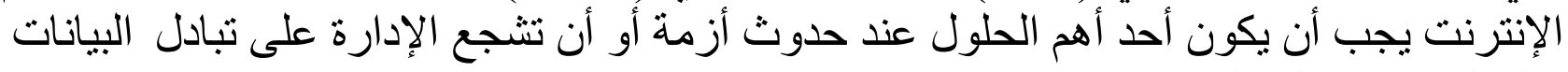
و المعلو ماتبين العاملين.

النتائج:

توصل البحث إلى النتائج الآتية

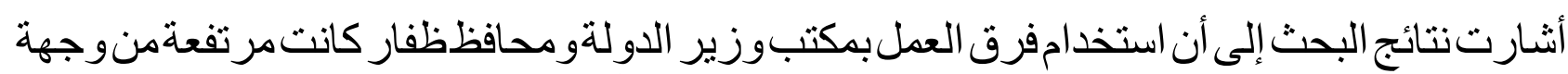

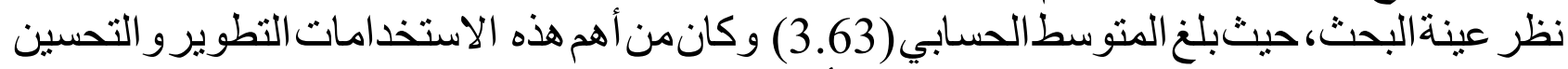

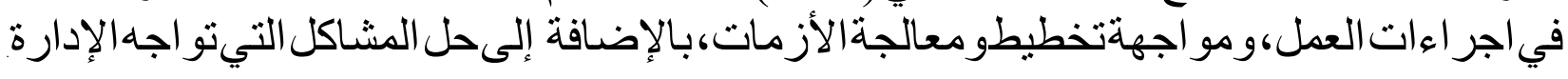

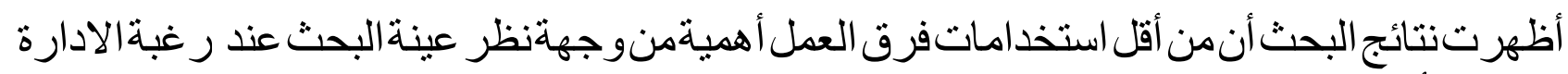

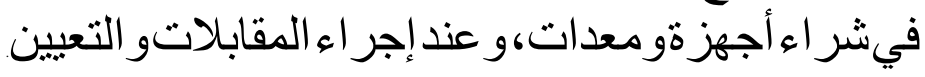

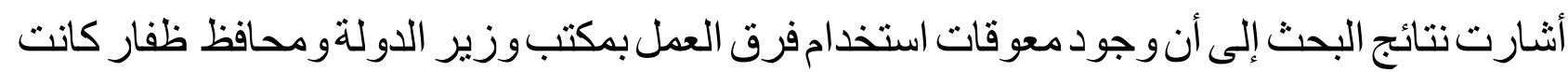

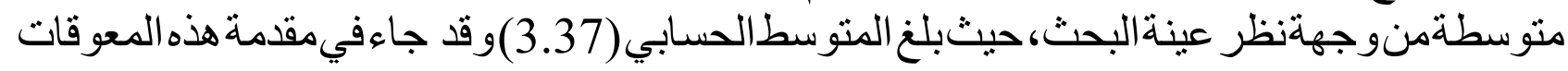

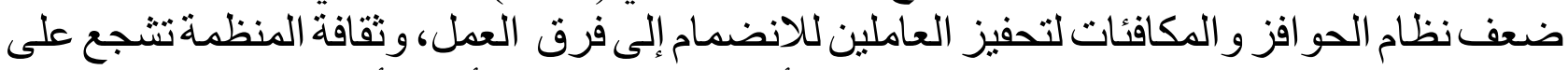

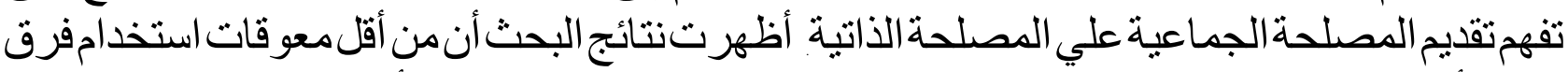

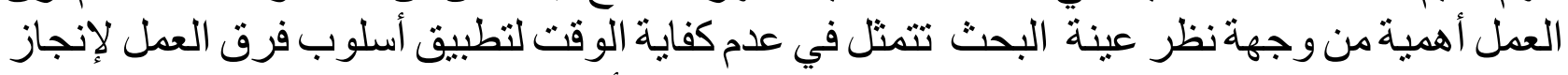

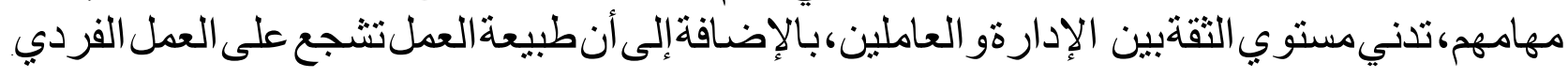

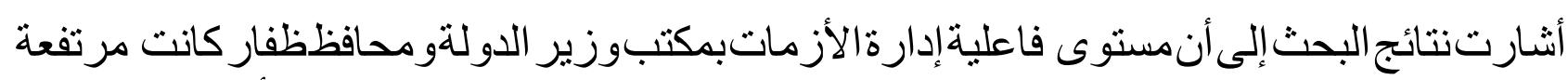

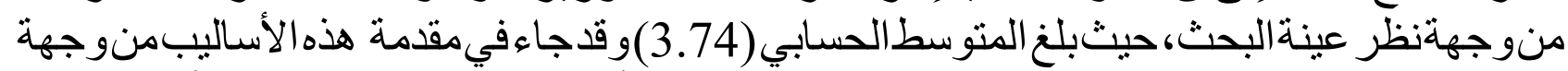

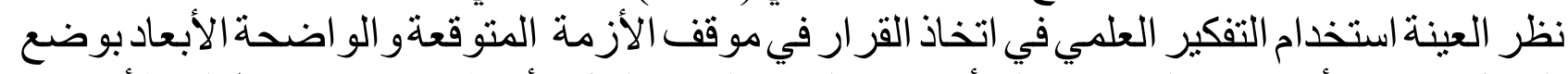

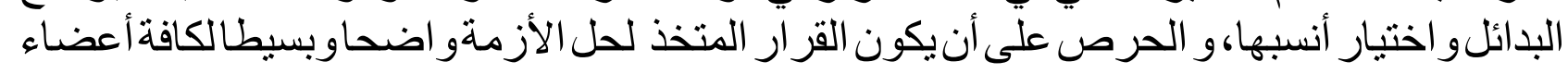
الفريق ليتمكنمنتفيذار أنسيها

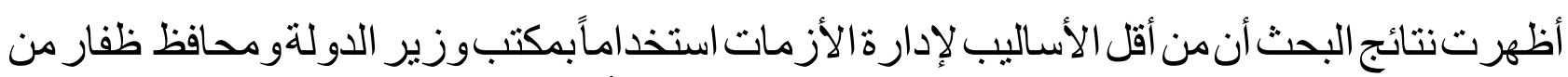

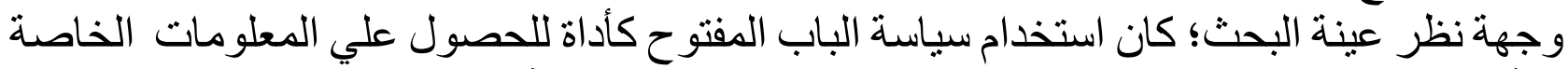

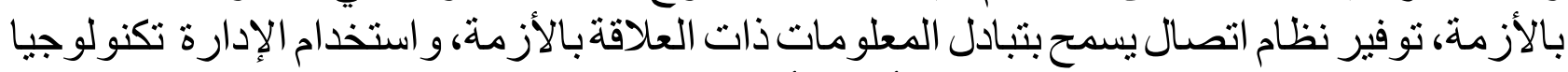

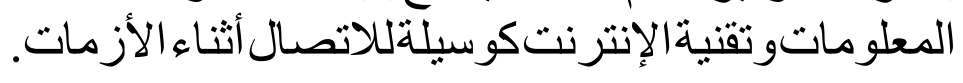

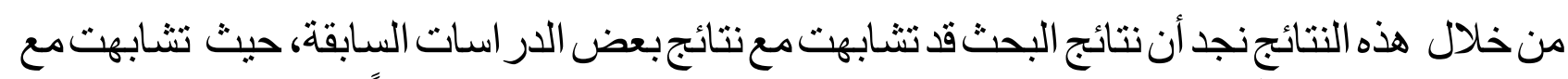

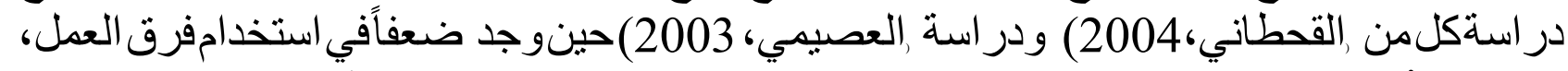

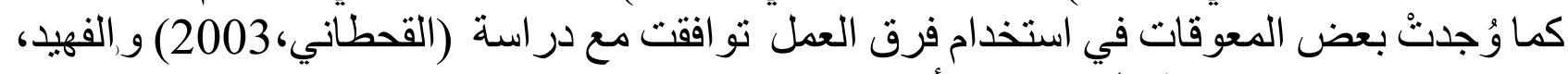

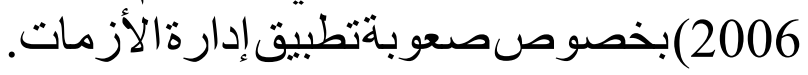


1- يتعين على الإدارة الا هتمامبدرجة أكبر باستخدام الأساليب الحديثةلمو اجهة الأزماتو استخدامها

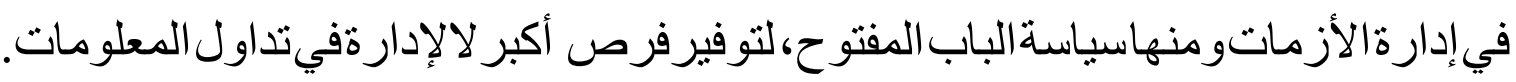

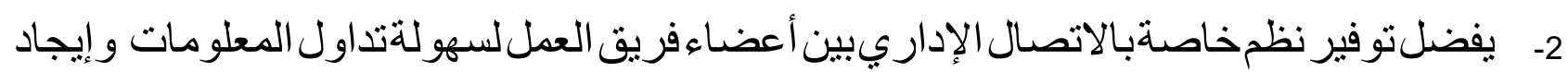

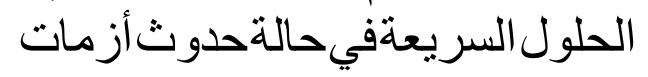

3- استخدامتكنولوجيا المعلومات الإنترنت كأهم الوسائل الخاصةبالاتصال لمعالجة الأزمات.

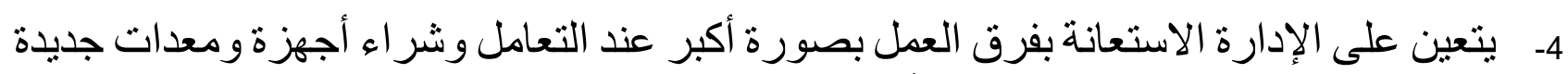

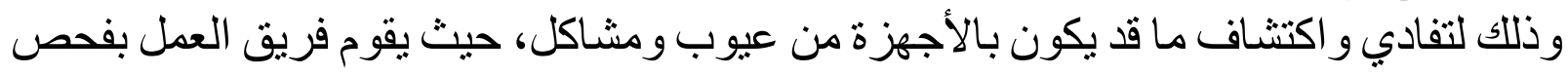

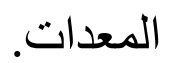

5- يفضل أنتستخدم الإدارةفرق العمل عند إجر اءمقابلات تعيين أشخاص جددوذلك لخبرة الفريقفيما

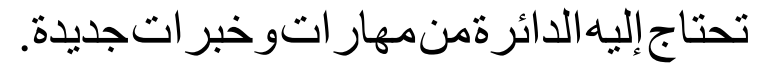
6- كمايستحسن قيام الدائرة بتأكيد أن العمل كفريق أفضل من العمل الفردي، واتئل والمصلحة العامة أهم من

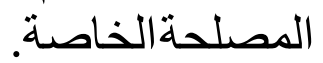

الخاتمة:

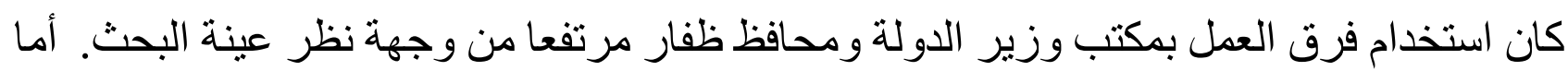

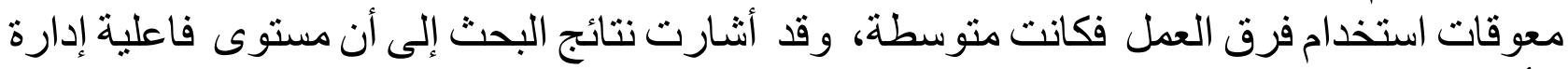

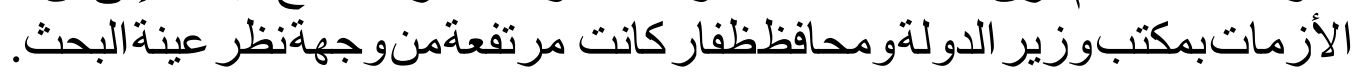

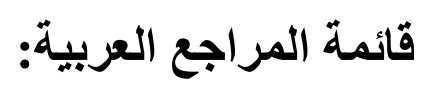
أبو خليل، ححمد إبراهيم .(2001). موقف مديري مدارس التعليم الاساسي من بعض الأزمات و التخطيط لمو اجهتها ـ مجلة مستقبل التربية العربية، المجلد السابع، العدد 21، القاهرة، مصر.

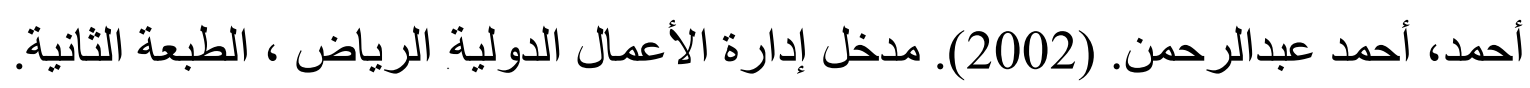

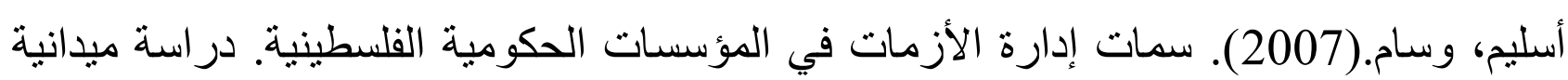
على وز ارة المالية في غزة، رسالة ماجستير، الجامعة الإسلامية ، غزة فلسطين.

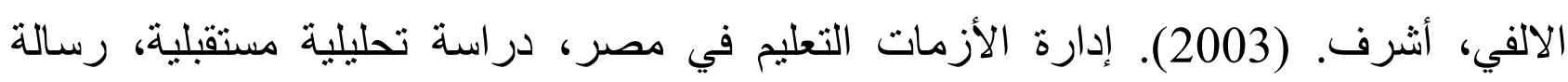
دكتور اه، جامعة، المنصورة، مصر. جاد الرب، سيد محم. (2005). السلوك التظيمي. السويس، مصر : مطبعة العشري.

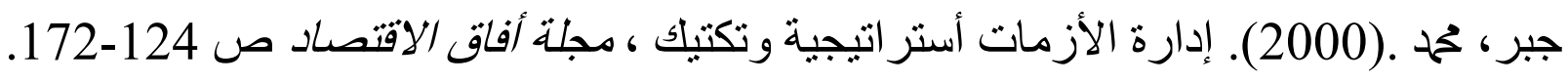

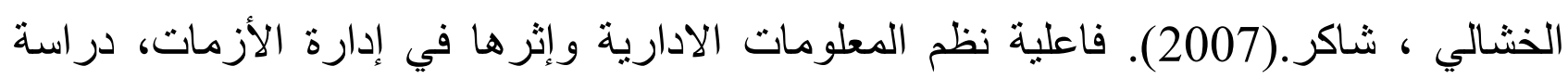
ميدانية في الثركات 
الصناعية الأردنية، الدجلة الأردنية في إدارة الأعمال. الأردن.

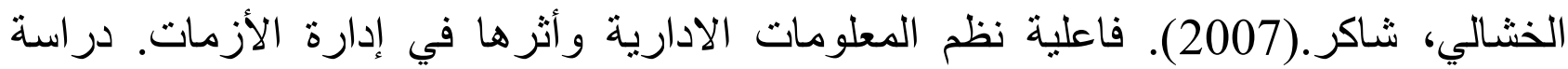
ميدانية في الثركات الصناعية الأردنية ، المجلة الأردنية في إدارة الأعمال، الأردن.

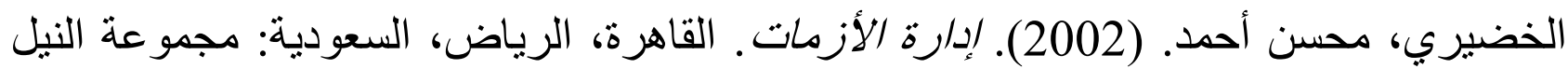
العربية للطباعة و النشر. الفر. خليل، بدر الدين. (2002). فرق العمل ودور ها في سلامة اتخاذ القرارات بالمنشأت السعودية:

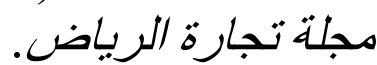
الرشيد، عادل. (2001). فرق العمل في منظمات الأعمال الأردنية. دراسة ميدانية لاتجاهات المديرين المعينين، (النين 